\title{
Halite karst geohazards (natural and man-made) in the United Kingdom
}

ANTHONY H. COOPER

British Geological Survey, Keyworth, Nottingham, NG12 5GG, Great Britain

COPYRIGHT @ BGS/NERC

e-mail ahc@bgs.ac.uk

$+44(-0) 1159363393$

+44 (-0)115936 3475

COOPER, A.H. 2002. Halite karst geohazards (natural and man-made) in the United Kingdom. Environmental Geology, Vol. 42, 505-512.

This work is based on a paper presented to the $8^{\text {th }}$ Multidisciplinary Conference on Sinkholes and the Engineering and Environmental impact of karst, Louisville, Kentucky, April 2001.

In the United Kingdom Permian and Triassic halite (rock salt) deposits have been affected by natural and artificial dissolution producing karstic landforms and subsidence. Brine springs from the Triassic salt have been exploited since Roman times, or possibly earlier, indicating prolonged natural dissolution. Medieval salt extraction in England is indicated by the of place names ending in "wich” indicating brine spring exploitation at Northwich, Middlewich, Nantwich and Droitwich. Later, Victorian brine extraction in these areas accentuated salt karst development causing severe subsidence problems that remain a legacy. The salt was also mined, but the mines flooded and consequent brine extraction caused the workings to collapse, resulting in catastrophic surface subsidence. Legislation was enacted to pay for the damage and a levy is still charged for salt extraction. Some salt mines are still collapsing and the re-establishment of the post-brine extraction hydrogeological regimes means that salt springs may again flow causing further dissolution and potential collapse.

Halite Salt Subsidence Geohazards Salt springs Brine Brine extraction

\section{Introduction}

In The United Kingdom, halite, or rock salt, occurs mainly within the Triassic strata of the Cheshire Basin, and to a lesser extent in Lancashire, Worcestershire and Staffordshire. It is also present in the Permian rocks of NE England and Northern Ireland (Fig. 1 and Notholt and Highley, 1973).

Where the saliferous Triassic rocks come to outcrop, most of the halite has dissolved and the overlying and interbedded strata have collapsed or foundered producing a buried salt karst. These areas commonly have saline springs, indicative of continuing salt dissolution and 
the active nature of the karst processes. The salt deposits were exploited using these springs from before early Roman times to Victorian times when more intense brine and salt extraction was undertaken. Halite dissolves rapidly and subsidence, both natural and mining-induced, has affected the main Triassic salt fields including Cheshire, Staffordshire, Worcestershire, coastal Lancashire and parts of Northern Ireland. Much of the mining has been by shallow brine extraction, the results of which mimic the natural karstification of the salt deposits.

Permian salt is present in The United Kingdom, at depth, beneath coastal Yorkshire and Teeside. Here the salt deposits and the karstification processes are much deeper than in the Triassic salt. The salt deposits are bounded up-dip by a dissolution front and collapse monocline. Salt has also been won from these Permian rocks by dissolution mining and some historical subsidence due to mining has occurred along the banks of the River Tees.

\section{Salt deposits in the UK}

The Triassic salt deposits in The United Kingdom were deposited in a semi-arid environment within mainly fault-controlled land-locked basins linked to the major depositional centres of the North and Irish Seas. The general Triassic sequence comprises thick sandstones and conglomerates overlain by red-brown siltstone and mudstone with interbedded halite and gypsum sequences. The Permian salt deposits form part of the Zechstein Group sequence that extends eastwards from The United Kingdom to Holland and Germany. Only the featheredge of the Zechstein Group is present on shore in The United Kingdom and the salt deposits are restricted to the coastal parts of northern England (Fig. 1). Here the Permian salt is interbedded with thick dolomite, mudstone and anhydrite formations. 


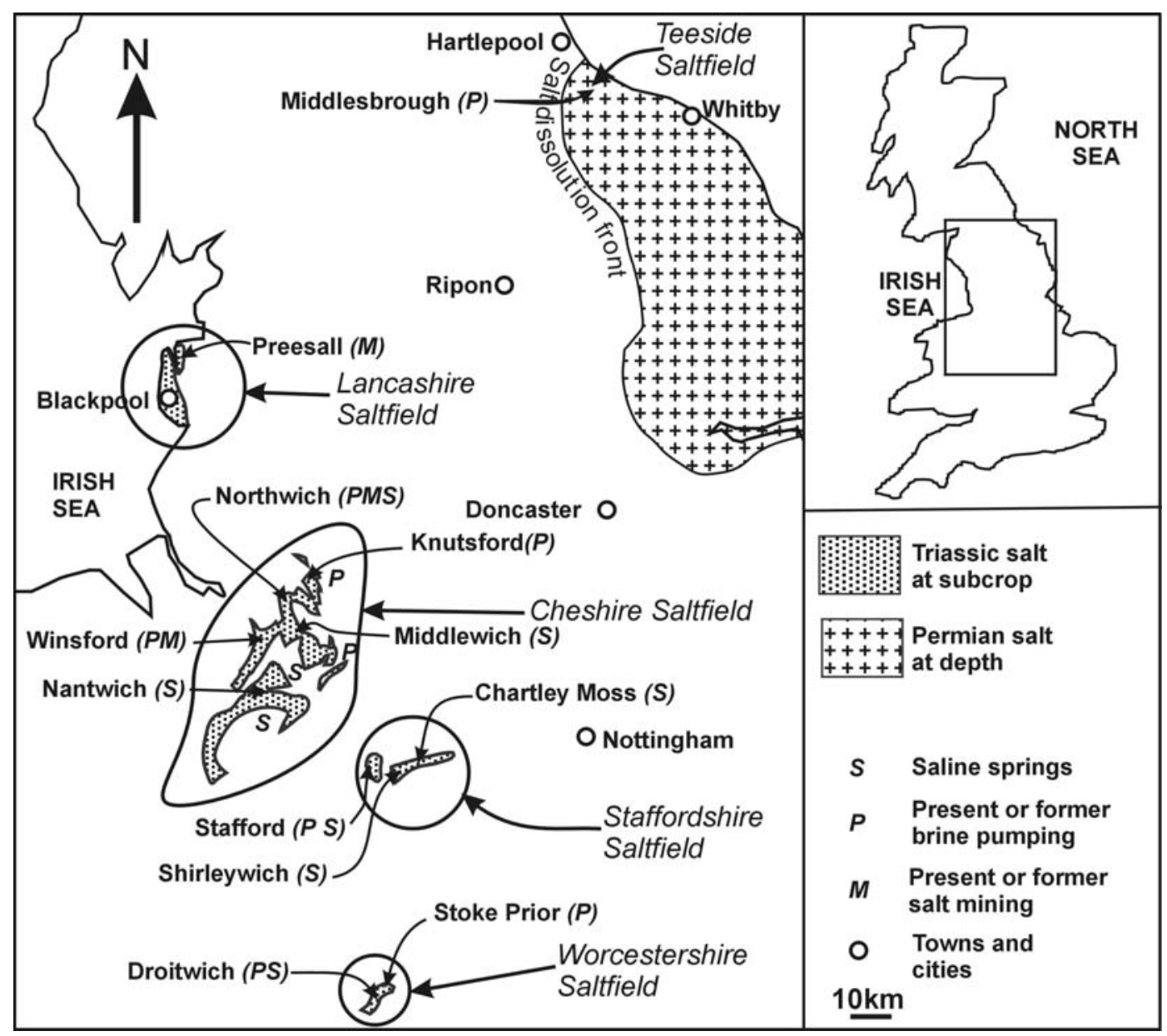

Fig. 1 The distribution of the salt karst and salt mining areas in England.

\section{Salt karst in the UK}

Where the Triassic saliferous rocks come to outcrop, salt karst has developed (Fig. 1) at depths of 30 to $130 \mathrm{~m}$. The development of this karst has been strongly influenced by groundwater flow and the modification of the groundwater regime during the last, and possibly earlier, glaciations. The last (Devensian) glaciation buried the north and central parts of The United Kingdom beneath a thick wet-based ice-sheet producing elevated groundwater heads linked to the hydrology of the ice-sheet (Howell and Jenkins, 1976). This elevated head is thought to have depressed and flushed out the saline waters forcing the dissolution surface of the salt to cut deeper into the sequence. When the ice-sheet melted, the groundwater regime changed and further dissolution of the salt occurred as new regional groundwater patterns formed. Because of the last glaciation, the depth of salt dissolution is commonly very deep. This mechanism may also help to explain why the dissolution extends down to about 130m in the Triassic salt of Cheshire, but to 3-400m in the Permian salt of northern England, where the cover of ice was probably much thicker. However, it must also be noted that the salt beds in 
the Permian probably would not come to outcrop because their facies is restricted to the deeper parts of the depositional basin (Smith, 1989).

The way in which the salt karst has developed is also dependent on the nature of the lithological sequence in which the salt beds were deposited. In the Triassic deposits, most of the salt is interbedded with units of siltstone and mudstone, commonly with gypsum. Where the groundwater has circulated and removed the salt, only the interbedded insoluble rocks remain as a breccia, concealed by the commonly less brecciated, but foundered cover sequence. The traditional term for the salt surface where the dissolution has occurred is "wet rock head” because it is from here that the original brine extraction took place. In contrast, the traditional name for the area where the salt has not dissolved because it is sealed beneath a cover of strata is “dry rock head” (Earp and Taylor, 1986; Evans and others, 1993 and Fig. 1). The area of wet rock head encompasses the salt karst, but the depth of the karst surface generally lies some $30-130 \mathrm{~m}$ below the ground surface and may even reach a depth of $180 \mathrm{~m}$ in Cheshire (Howell, 1984).

The wet rock head area is the zone in which dissolution has occurred and the foundered ground above this zone commonly has numerous collapse features. These range from enclosed hollows 20-200m across to linear depressions up to several kilometres long. These depressions were called "brine runs" by the early brine miners and it was into these, and the brine springs that they sunk their extraction wells.

\section{Historical records of salt springs}

\section{Place names that indicate salt springs}

Historical maps and records of the salt areas record many brine spring locations revealed by the place names. In Roman times, sources of salt were noted as Salinae. In Medieval times the locations of salt springs were indicated by the term wich or wyche (Calvert, 1915; Room 1988; Mills, 1998). Many of these places were later differentiated so that, for example, in Cheshire, the towns of Nantwich, Middlewich and Northwich were established. Nantwich referring to the named wich (Nametwilhc in 1194), Middlewich to the middle wich and Northwich to the northernmost wich (Mills, 1988). Likewise in Droitwich the different springs were individually named as Netherwich, Middlewich and Upwich corresponding to their places in the town and lower, middle and upper locations along the River Salwarpe (Woodiwiss, 1992, Fig. 120 ; Hurst, 1997, Fig. 2). The name of the river here probably indicates salt (possibly derived from the Roman name of Salinae) and a clay floodplain or 
warpe, though Mills (1988) and Woodiwiss (1992) suggests the name probably only means dark coloured silty land. Many other places include wich or wyche at the start or end of their name and many of these are mentioned below. The current name for the administrative district which includes Droitwich is Wychaven (Room, 1988).

\section{$1^{\text {st }}-10^{\text {th }}$ Century and earlier salt springs}

It is documented that the natural brine springs at Northwich were exploited in pre-Roman times (Calvert 1915), but there is very little evidence remaining. At Droitwich, a possible Iron Age brine boiling hearth was excavated at the site of the Upwich brine spring (Hurst 1997) and probable remains of Iron Age salt pits were found elsewhere in the town (Woodiwiss, 1992). In contrast, the Roman remains at Upwich were extensive and showed a wellorganised salt industry. There was a wood-lined well and a probable brine lifting structure (Hurst 1997) that may have incorporated some sort of counterbalanced bucket mechanism. The importance of Droitwich as a salt producer in Roman times is indicated by its Roman name of Salinae a name also applied to Middlewich (Room, 1988) and used for Saltzburg in Austria. Droitwich has been recognised as the Salinae noted in Claudius Ptolemy’s Geography compiled in c. AD 140-150 and as the place named Salinis noted in the Ravenna Cosmography compiled soon after AD 700 (Woodiwiss, 1992). The Roman names and archaeological evidence indicate that brine was flowing to the surface at Droitwich, Middlewich and Northwich since before the start of written history.

The Early Medieval period or Dark Ages is poorly documented, but one of the earliest references to Droitwich salt was in 716 when King Ethelbald granted a salt pit on the south side of the River Salwarp to Evesham Abbey (Whitelock, 1954; Hoskins, 1955). Salouuarpe (Salwarpe) was also mentioned in 817 (Mills, 1998) and brine springs and salt furnaces were recorded at Droitwich in 816 and 906 (Calvert, 1915). In 962, Bishop Oswald granted Beonetlaege (Bentley) four saltpans at Upwich (Droitwich) and enough woodland at Bradanlaege (Bradley) to fuel them. Wychbold was mentioned in 692 (Mills, 1998) and Saltwic (Droitwich) in 884-901 (Woodiwiss, 1992).

\section{$11^{\text {th }}-16^{\text {th }}$ Century records of salt springs}

The brine extraction and boiling industry established by the Romans flourished in Medieval times and was well documented in the Domesday Book. This was compiled for William $1^{\text {st }}$ as an inventory of his newly acquired lands in 1084-1086 with numerous “wiches” and salt houses recorded. (Calvert, 1915; Morris, 1978; Room, 1988; Hinde, 1985). Many places are 
noted in the Domesday Book as having "salt houses”, but commonly they belonged to estates outside of the salt areas and many of the entries note "salt houses at wich" without stating exactly the wich to which they refer. Hoskins (1955) noted that at Droitwich King William had eighty-five salt pans and sixty-eight manors and estates that had the rights to receive salt. Several dedicated roads or "salt ways" were established to transport the produce and some of these may have dated back to Roman times. Places recorded in the Domesday Book and later documents that certainly had salt springs and salt pans include: Droitwich (Wich 1086, Drilhtwych 1347); Middlewich (Wich, Mildestuich, 1086); Nantwich (Wich 1086, Nametwilhc, 1194); Northwich (Wich, Norwich, 1086); Salt (Selte 1086); Wychbold (Wicebold 1086); Salwarpe (Salewarpe, 1086) (Calvert, 1915; Room, 1988; Hinde, 1985). The importance of Droitwich as a salt producer is shown by the fact that in 1215 King John gave Droitwich its charter in exchange for a yearly rental of $£ 100$ for the salt springs (Poole and Williams, 1980).

\section{$17^{\text {th }}-18^{\text {th }}$ Century records of salt springs}

Most of the early records of salt springs relate to deeds, land ownership changes and taxes, but in the $17^{\text {th }}$ Century the scientific investigation of numerous natural, physical and chemical phenomena began. In 1669 William Jackson a “Doctor of Physick” reported details of the Cheshire salt springs to the Royal Society. In 1678, Dr Thomas Rastell reported to the same society on the salt springs at Droitwich.

Jackson's description of the Cheshire salt springs notes that the salt pits were 3-4 yards deep (2.7-3.6m), though at Nantwich the spring was 7 yards $(6.4 \mathrm{~m})$ from the surface. He noted springs along the River Weever (now Weaver) at Hankilow (now Hankelow), Hatheton, Ofterson (probably Austerson), Bartherton (now Batherton), Nantwich, Weever (now Weaver), Leftwich, Northwich, and also at Midlewich (Middlewich) nearer the River Dane than the Weaver. He noted that the salt was aggressive to vegetation and that the water in the brine pits was very cold. In addition he recorded that there were numerous mosses with turf that could be cut, dried in the sun (and presumably used for fuel). He recorded that:

“these Mosses seem to be places undermined by some Subterraneous streams; or by the dissolution of some matter, that made them equal with the rest of the ground formerly: In which conjecture I am confirmed by this, That near a place of My Lord Cholmondeley's, called Bilkely, (now Bickley) about 9 or 10 years since, not far from one of these Mosses, without any Earth-quake, fell in a piece of ground about 30 yards over (more than $27.4 \mathrm{~m}$ across), with a huge noise, and great Oakes growing on it fell with it together; which hung 
first with part of their heads out, afterwards suddenly sunk down into the grounds so as to become invisible. Out of which Pitt they drew Brine with a pitcher tyed to a cart rope, but could then find no bottom with the ropes they had there: Since, the Pitt is filled up with water, and now doth not taste Salt, but a very little brackish, a very small rindlet (stream?) passing through it. The nearest salt springs to it are at Dartwich about 3 miles from it, belonging to the present Lord Keeper, and My Lord Cholmondeley” (Jackson, 1669; Dartwich is not shown on any of 1880 maps or later maps for the area).

Another record of this subsidence is presented by Ormerod (1848) who noted that the event took place on $8^{\text {th }}$ July 1659 at the place called Barrel-fall, and that it was now dry and overgrown with brush wood. As part of his scientific work, Jackson (1669) recorded and measured the concentration of salt in the brine noting the strongest spring at Midlewich (Middlewich) yielded one fourth part of salt, but had a low flow. In contrast that at Nantwich yielded one sixth part and had a large yield. He found that the strength of the brine was stronger when the pit had been left to rest and not exploited for some time.

Rastell described the salt springs of Droitwich in 1678 noting that: "There are many Salt Springs about the town, which is seated by a Brook-side called Salwarp-Brook, which arise both in the Brook and in the ground near it, though there are but three Pits that are made use of." He recorded the Upwich Pit as 30 feet $(9 \mathrm{~m})$ deep and 10 feet square $(3 \mathrm{~m})$ with three springs rising in the bottom of the excavation into ground that was originally a bog. $\mathrm{He}$ noted the brine was very cold and that the strength of the brine changed as the pits were exploited. The strongest brine at Upwich yielded about one quarter its weight in salt. The production of crystallised salt for each day was given as 450 bushels from Upwich, 40 bushels from best pit at Netherwich and 30 bushels from the worst pit. A bushel has a volume of 8 imperial gallons (36.4 litres), which using a dry density of 1.154 for loose salt crystals (Salt Institute web page figure http://www.saltinstitute.org/15.html ) would equate to about $42 \mathrm{~kg}$ of salt in a bushel and a daily salt abstraction at Droitwich of about $21,840 \mathrm{~kg}$. Using a specific gravity of 2.165 for solid crystalline salt, this would equate with about 10 cubic metres of rock salt a day dissolving naturally in the surrounding area to feed the springs. The actual figure may have been more since much of the brine may have leaked naturally into the river through Quaternary river gravel deposits.

The near natural flow of the springs at Droitwich was dramatically changed in 1725 when gypsum beds confining the brine beneath the springs were penetrated and greater volumes of brine were produced. Parkinson (1884), quoting a Dr Nash, commented that at one time nine tenths of the brine flow ran to waste. He also recorded that in 1779 Richard 
Norris sank a well through the red marl and gypsum, striking a brine spring at a depth of 80 feet (26m) from the surface. The brine rushed upwards with such force that one or two workmen were killed. When such deep and extensive exploitation of the brine began the nature of the salt karst started to change dramatically.

\section{The influence of salt mining and brine extraction}

Salt mining and brine extraction have played a major role in the modern development of the salt karst in the Cheshire and Worcestershire areas. The original method of getting the salt was to tap into the natural brine springs, a technique that satisfied the Roman and Medievel salt industries. In the $16^{\text {th }}$ to $18^{\text {th }}$ Centuries the demand for salt became much greater and wells were sunk on the sites of the brine springs to tap into the deeper more concentrated and more reliably available brine. From the late $16^{\text {th }}$ Century reciprocating pumps were developed to draw up the brine (Woodiwiss, 1992).

From the $18^{\text {th }}$ Century onwards, boreholes with pumps were developed and the extraction of even deeper brine became possible. The technique was to tap into the natural underground brine runs that mainly existed at the interface of the rocksalt and the overlying deposits and collapsed materials. This method of uncontrolled brine extraction was referred to as "wild" brining. The method induced brine to flow towards the extraction boreholes aggravating the existing subsidence features or causing linear subsidence belts spreading along strike from the boreholes. It was this uncontrolled way to abstract brine that caused the enlargement of the natural brine runs and resulted in widespread subsidence for considerable distances from the extraction points. The large-scale abstraction of brine in this way enhanced the development of the natural salt karst into an unnatural form.

In the late $19^{\text {th }}$ and early $20^{\text {th }}$ Centuries the salt deposits were worked mainly by two methods: conventional mining and wild brine solution mining. Most of the conventional mining was in shallow "pillar and stall” mines with networks of tunnels commonly separated by narrow salt pillars. In many places the salt was also worked by pillar and stall mining based on very large extraction rates and very small pillars for support. Many of these mines were fairly near to the wet rock head areas and flooding was a common hazard. Not wishing to waste valuable salt, many of the flooded salt mines were also pumped for brine, a technique referred to as "bastard" brining. This produced catastrophic mine collapse inducing surface subsidence on such an enormous and unprecedented scale that it destroyed whole areas of towns and factories. Around Northwich and Middlewich, the resulting subsidence was catastrophic and widespread. New lakes, locally called "meres” or "flashes”, appeared almost 
daily and many were hundreds of metres across including Moston Flash near Elworth (Earp and Taylor, 1986; Waltham, 1989; Waltham and others, 1997).

The subsidence in Cheshire was so severe that a Parliamentary investigation of the problems was commissioned (Dickinson, 1873). Subsequently, an Act of Parliament was passed that placed a levy on all locally extracted salt. This levy, which funded building reconstruction and compensation payments, is still made by the "Cheshire Brine Subsidence Compensation Board”, but at a lower rate to reflect the reduced risk from modern extraction (Collins, 1971). Both the brining and the mining caused major perturbations to the salt karst system and the brine flows related to it.

Modern salt extraction is carried out in three ways. There is one relatively small licensed producer extracting wild brine from relatively shallow boreholes sunk into the wet rock head. However, most modern salt extraction takes place either in deep, dry, pillar and stall mines at depths of $125-170 \mathrm{~m}$, or by controlled brine extraction, at depths of $150-300 \mathrm{~m}$, leaving large, deep underground chambers that are left flooded and filled with saturated brine. The expectation is that these brine cavities and mines will remain stable and some are used for waste disposal (Northolt and Highley, 1973).

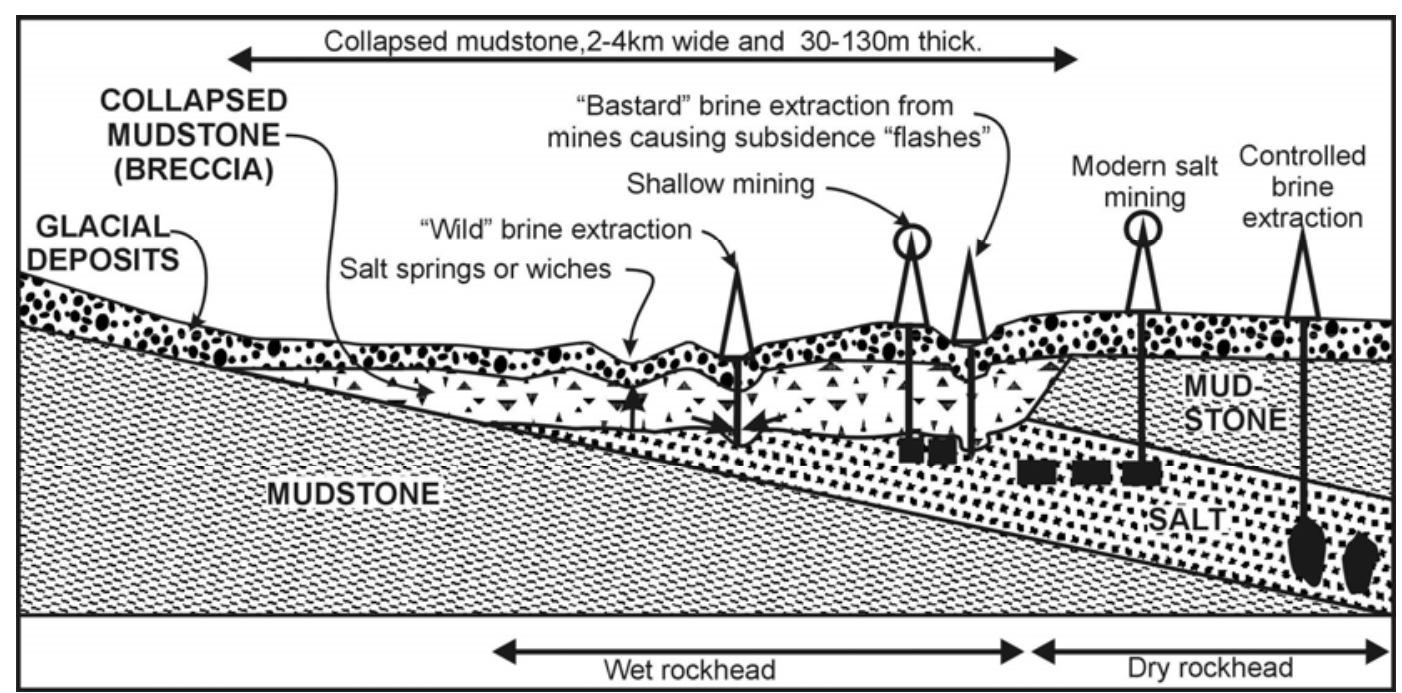

Fig. 2. Cross-section through a typical Triassic salt area showing the dissolution zone, the dissolution mining and the present mining situation.

\section{The Salt karst areas of the United Kingdom}

\section{Cheshire}

Two salt formations are present in the Triassic Mercia Mudstone Group in Cheshire. These are the Wilkesley Halite Formation (up to 300m thick) near the top and the Northwich Halite 
Formation (up to 200m thick, with mudstone partings) in the middle of the group (Earp and Taylor, 1986; Evans and others, 1993, Wilson, 1993). The sequence between and below the salt formations is dominantly red-brown gypsiferous and dolomitic mudstone and siltstone. The salt karst has developed below the collapsed and foundered strata over wet rock head. Brine escaping from this dissolution zone formerly emerged at the surface as brine springs, but subsequent brine extraction caused most of them to cease flowing. In Cheshire, brine springs occurred in many places including Northwich, Middlewich, Nantwich, Winsford. They were also present near Whitchurch (Shropshire) at Higher Wych and a place formerly called Dirtwich. Natural subsidence has occurred sporadically throughout the salt field, one of the earliest records being in 1533 at Combermere Abbey near Whitchurch (Sherlock, 1921). Another was recorded at Bilkely in about 1659 near Cholmondeley Castle (Jackson, 1669; Ormerod, 1848). Numerous buildings at Wybunbury near Crewe were damaged by salt dissolution subsidence in the late $19^{\text {th }}$ Century and the cause may have been natural since the nearest brine extraction was over 10 miles away (De Rance, 1891). Many natural lakes such as Rostherne Mere near Knutsford were also formed by salt dissolution since the end of the Devensian ice-age and the Cheshire saltfield is dotted with meres formed in this way (Waltham and others, 1997).

The Cheshire saltfield has a long history of exploitation growing from its first pre-Roman development around the salt springs into a major industry. Some details of the mining and damage caused are mentioned above in the historical and mining sections. The uncontrolled extraction of brine resulted in an artificial lowering of the brine/freshwater interface. This allied with groundwater abstraction from adjacent aquifers has disturbed the brine above the karst surface and introduced fresh water into some areas (Howell and Jenkins, 1976). However, recent geochemical sampling (British Geological Survey, 1999) has shown that brine from springs is entering the rivers in the Cheshire saltfield again. From river flow volumes, and the content of salt in the water it should be possible to calculate the amount of salt being removed annually from the Cheshire saltfield. However, not all the salt in the rivers is from the salt beds, since much of the British river chloride solute load is derived from the British maritime precipitation (Walling and Webb, 1981) and anthropogenic sources such as road de-icing and sewage works (British Geological Survey, 1999).

\section{Staffordshire}

The salt deposits under the town of Stafford lie in a synclinal structure faulted along its eastern side (Arup Geotechnics, 1990). The salt occurs interbedded with mudstone in a 
sequence 50-65m thick within the Mercia Mudstone Group. The near-surface deposits have dissolved to a depth of around 50m (wet rock head) and the salt has largely dissolved adjacent to the eastern fault zone. The natural salt springs around Stafford are not well documented, but the town is surrounded by the villages with names ending in wich; these include Baswich, Milwich, Gratwich, Colwich and Shirleywich (along with the village of Salt), all suggesting the presence of brine springs. The springs at Shirleywich have a long history of exploitation from the $17^{\text {th }}$ century to the late $18^{\text {th }}$ century. The Shirleywich springs, and nearby ones at Weston, appear to be fed from salt deposits lying to the north-east in a belt running through Chartley Moss and other small lakes. Lying 5km to the NE of Shirleywich, Chartley had the strongest saline springs in Staffordshire in the mid $16^{\text {th }}$ century (Sherlock, 1921). Chartley Moss is a fresh-water pond and floating bog formed in a salt dissolution subsidence area. Localised collapse here causes minor seismic events that are felt on the surface of the bog, thus providing evidence of active salt dissolution and subsidence beneath the site (A. Brandon, pers comm. 2000). Brine was extracted from beneath the town of Stafford from about 1890 until a court case in 1970, over substantial subsidence damage, caused the cessation of wild brine extraction from the area. Only something like $10 \%$ of the volume of salt removed by this brine extraction has been accounted for by recorded subsidence and further subsidence may occur in the area. The main brine run trends NNE towards the extraction boreholes and about 2 square kilometres of land have been affected by subsidence. Since the 1940's about 20 properties have been demolished and 500 severely damaged (Arup Geotechnics, 1990).

\section{Lancashire}

The Lancashire coast beneath Blackpool and Preesall is underlain by the Triassic Mercia Mudstone Group which includes several salt units. Two impersistent units, the Rossal Halite and the Mythop Halite, occur low in the sequence and a third more persistent unit, the Preesall Halite occurs high in the sequence (Wilson, 1990; Wilson and Evans, 1990). The Preesall Halite was formerly worked in salt mines at Preesall on the east side of the River Wyre. The east of the saltfield is marked by the Preesall Fault Zone. Adjacent to this the westerly dipping salt comes near to crop, but groundwater circulation has dissolved the salt to a depth of between 50 and $100 \mathrm{~m}$ resulting in a collapse breccia down to wet rock head (Wilson and Evans, 1990). Though there are no confirmed saline springs in the area, their most likely position would be at the coast emerging beneath the sea. Sherlock (1921) notes the name of the village of Salwick near Kirkham just south of the district (however, because the coast is 
nearby, this name could equally relate to the production of sea salt). Probable subsidence areas, in which post-glacial peat deposits have formed, are also recorded in the district, especially around Mythop (Wilson and Evans, 1990). These subsidence areas range from 30 to $150 \mathrm{~m}$ across and contain up to $10 \mathrm{~m}$ of peat formed over the last 12,000 years. They give an indication of the amount and rate of salt karstification that has taken place beneath the area.

\section{Worcestershire}

The Triassic saliferous rocks in Worcestershire occur in the Mercia Mudstone Group and include the upper and a middle sequences of salt beds approximately equivalent to the Cheshire salt beds further north. The saliferous sequence is about $90 \mathrm{~m}$ thick of which $40 \%$ comprise siltstone and mudstone units. In Roman times, the town of Droitwich was called Salinae, a name indicative of the brine springs that rose there in the valley of the River Salwarpe. The three main springs of Netherwich, Middlewich and Upwich were noted by Rastell 1678 and some of their excavations described by Woodiwiss (1992) and Hurst (1997). In the $17^{\text {th }}$ century shafts were sunk that increased the brine flow from the Droitwich springs. In the $18^{\text {th }}$ century deeper pits encountered artesian brine that could not be controlled and largely ran to waste (Poole and Williams, 1981). Some salt mining was undertaken in the district, but it encountered natural brine runs and the subsequent exploitation was by brine extraction that ceased in 1972. The brine abstraction caused the natural brine springs at the surface to dry up. It also caused a belt of subsidence along, and spreading out from, the course of the original sinuous brine run. The brine run follows the wet rock head of the strata which dips to the south-east and it has a north-east trending course through Droitwich and Wychbold to the former salt works at Stoke Prior. This is near the ancient Upton Warren pools dating from about 42,000 years BP, preserved in alluvial deposits and inferred to have formed in brackish water conditions (Coope and others, 1961). Where the salt has dissolved, the zone of collapse over the wet rock head extends down to a depth of about $90 \mathrm{~m}$ forming a belt $1-2 \mathrm{~km}$ wide and $12 \mathrm{~km}$ long. The route of the original brine run was the area in which the most subsidence and building damage occurred in the $19^{\text {th }}$ century. In the 1980 's after the cessation of brine extraction, the brine levels began to rise. This caused Poole and Williams (1981) to speculate that in the future brine would flow again from the sites of the original springs that were used by the Romans. The fact that brine now flows naturally to the surface here is proved by a recent geochemical survey (British Geological Survey, 1999) which showed stream water Chloride concentrations of 3100 and $3400 \mathrm{mg} / \mathrm{l}$ on adjacent sites to the east of Droitwich. 


\section{Northern Ireland}

Triassic saliferous rocks are present in the area around Carrickfergus and Larne, bordering on Belfast Loch in Northern Ireland. The Triassic sequence includes up to 200m thickness of salt, proved in the Larne Borehole, but in the Carrickfergus salt field only about 40-50m has been proved. The salt deposits are largely protected from groundwater circulation by the overlying sequence and there is no record of wet rock head and extensive brecciation such as that found in Cheshire (Griffith and Wilson, 1982). A salt spring was known at Eden, where salt mining subsequently developed, and slight brecciation of the sequence was recorded in a few boreholes, but was not extensive. The most spectacular dissolution feature recorded in the area was the collapse of the Tennant Salt Mine in 1990 (Griffith, 1991). This mine was a conventional pillar and stall mine, but subsequent owners removed substantial amounts of brine from the abandoned workings. This dissolved the pillars and produced a large crown hole with concentric failure planes and a depression about 130m across.

\section{Teeside and Yorkshire}

In the north of England, salt is present in the Permian strata of the Zechstein Group. This evaporite and carbonate sequence extends from northern England eastwards beneath the North Sea to Germany and beyond. Only the marginal part of the Zechstein basin encroaches onshore in England where it includes thick units of anhydrite, halite and potash. The salt and potash deposits are currently mined by pillar and stall workings near the coast at Whitby. Here they are up to about 80m thick and occur at depths of 1100-1250 metres (Woods, 1973). The halite was also been extracted by dissolution at Teeside in the early $20^{\text {th }}$ Century (Tomlin, 1982) and its presence was largely responsible for the development of the chemical industry in the area. Anhydrite was also formerly mined here at Billingham (Raymond, 1960). The salt karst features on Teeside are very deep-seated and may be palaeokarst or, as discussed earlier, may relate to deep dissolution during the last ice-age. At the coast the salt is present at a depth of about 500m. Westwards up-dip there is a dissolution front in the salt (British Geological Survey 1987) and the overlying strata have collapsed and formed into a west-facing subsidence monocline (Fig. 3). Coming further up-dip the anhydrite units in the sequence pass into gypsum at depths of between 120 and $60 \mathrm{~m}$ and this too passes into another dissolution front with an associated subsidence monocline (Fig. 3 and Cooper, 1998). Though salt extraction by dissolution has largely ceased on Teeside, but some subsidence has occurred and may occur in the future. 


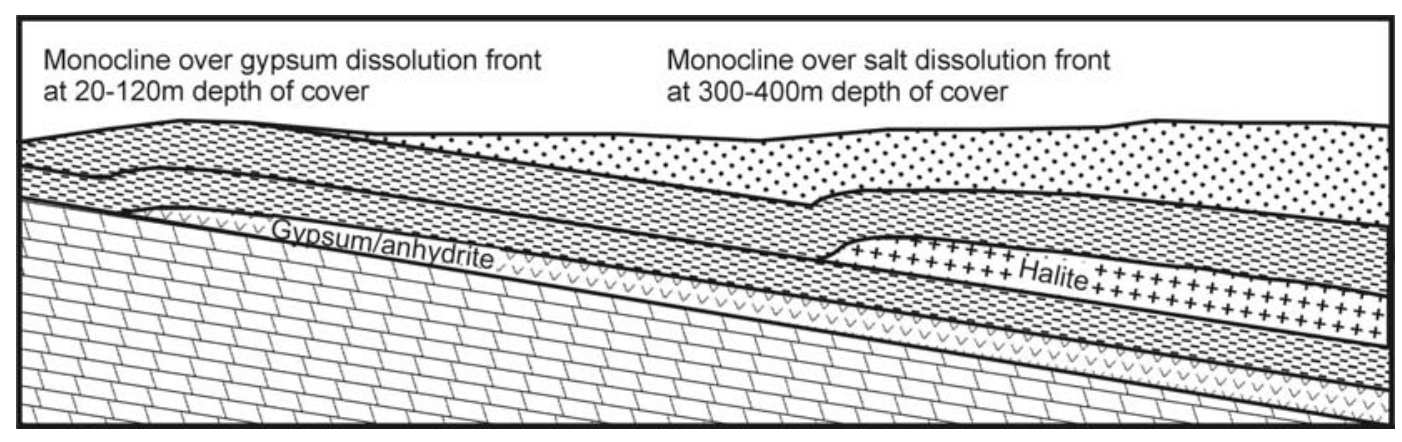

Fig. 3. Simplified cross-section through the dissolution fronts of the Permian salt and gypsum/anhydrite in northeast England. In reality, there are several sequences of anhydrite and salt that can each produce their own monoclinal structures.

\section{Planning for soluble rock geohazards}

Current planning procedures ensure that the modern exploitation of salt deposits lies largely outside of urban areas so that risks are considerably reduced. Furthermore, except for one natural brine extractor, the majority of the salt is mined either in deep dry mines, or by controlled brine extraction from depth. However, there is still a legacy of problems related to the salt deposits. These include old salt mines that have not collapsed, and compressible or unstable collapsed ground over former salt mines. In addition, natural salt dissolution at the rockhead interface, between the salt deposits and the overlying superficial deposits, can cause ground engineering problems and corrosive saline groundwater. With the ending of most near-surface mining and brine extraction, the hydrological system has, or is in the process of, re-balancing itself. It may be expected that natural groundwater flows will be re-established through the disrupted saltfields and further subsidence problems may occur. The accurate mapping of the rock salt and associated deposits, plus an understanding of their dissolution and collapse characteristics, can help development and planning in these subsidence-sensitive areas. These problems can then be reduced by careful planning and construction or remediation of former mines. In some places, such as Teeside, the local planning guidelines for development in former salt dissolution extraction areas (Morris, 1975) place a zone, that is considered to be susceptible to subsidence, of between $150 \mathrm{~m}$ and $300 \mathrm{~m}$ radius around every former brine extraction borehole in the area. The size of this buffer zone appears to relate to the depth and amount of salt extracted from each hole. In these areas, it is recommended that avoidance or special precautions should be taken for certain types of construction. In Cheshire collapse of some former mines are causing subsidence and their remediation is being considered. In most of the salt karst areas, there is a legacy of difficult ground conditions produced by natural and man-made causes. 


\section{Acknowledgements.}

This paper has benefited from useful discussions with Dr Tony Waltham, Professor Martin Culshaw and Dr John Lamont-Black. Dr Andy Farrant, Dr Ian Williamson and Alan Forster are thanked for critically appraising the manuscript. Published with the permission of the Director, British Geological Survey (NERC). The author acknowledges the contribution made towards this work by the ROSES (Risk of Subsidence due to Evaporite Solution) Project; ENV4-CT97-0603 and IC20-CT97-0042 funded by the EU Framework IV Programme.

\section{References}

Arup Geotechnics (1990) Review of mining instability in Great Britain, Stafford brine pumping. Vol. 3/vi. Arup Geotechnics for the Department of the Environment.

British Geological Survey (1987) Stockton Sheet 33. Solid and Drift.1:50 000 (Southampton: Ordnance Survey for the British Geological Survey).

British Geological Survey (1999) Regional geochemistry of Wales and part of west-central England: stream water.

(Keyworth, Nottingham: British Geological Survey). 110pp.

Calvert AF (1915) Salt in Cheshire. Spon Ltd, London, 1206 pp.

Collins JFN (1971) Salt: a policy for the control of salt extraction in Cheshire. Cheshire County Council.

Coope GR, Shotton, FW and Strachan, I (1961) A late Pleistocene fauna and flora from Upton Warren, Worcestershire. Philosophical Transactions of the Royal Society of London. 244. (Series B): 379-417.

Cooper AH (1998) Subsidence hazards caused by the dissolution of Permian gypsum in England: geology, investigation and remediation. In: Maund JG and Eddleston M (eds) Geohazards in Engineering Geology. Geological Society, London, Engineering Special Publications, 15, pp 265-275.

De Rance CE (1891( Subsidence at Wybunbury, near Crewe. Transactions of the Manchester Geological Society. 21: 197199.

Dickinson J (1873) Report on the Rock-Salt Mines and Brine Pits relative to the Landslips, for Her Majesty's Secretary of State for the Home Department. 53pp.

Earp JR and Taylor, BJ (1986) Geology of the country around Chester and Winsford. Memoir of the British Geological Survey, Sheet 109.119 pp.

Evans DJ, Rees JG and Holloway S (1993) The Permian to Jurassic stratigraphy and structural evolution of the central Cheshire Basin, Journal of the Geological Society, London, 150: 857-870.

Griffith AE (1991) 'Tennant’s Ills’. Ground Engineering. 21: 18-21.

Griffith AE and Wilson HE (1982) Geology of the country around Carrickfergus and Bangor. Memoir of the Geological Survey of Northern Ireland, Belfast, HMSO. 118pp.

Hoskins WG (1955) The making of the English Landscape, Hodder and Stoughton/Pelican, 326pp.

Howell FT (1984) Salt karst of the Cheshire Basin, England. In: Castany G, Groba,E. and Romijn E. Hydrogeology of karstic terranes. International contributions to hydrogeology, Vol. 1. International Association of Hydrogeologists. pp 252-254.

Howell FT and Jenkins PL.(1976). Some aspects of the subsidences in the rocksalt districts of Cheshire, England. Publication No 121 of the International Association of Hydrological Sciences, proceedings of the Anaheim Symposium, December 1976. pp507-520. 
Hinde T (1985) The Domesday Book; Englands Heritage, then and now. Phoebe Phillips Editions. 351pp.

Hurst JD (1997) A multi-period salt production site at Droitwich, Excavations at Upwich. Council for British Archaeology, Research Report 107, 164pp.

Jackson W (1669) Some Inquiries Concerning the Salt-Springs and the Way of Salt-Making at Nantwich in Cheshire. Philosophical Transactions, 4: 1060-1067.

Mills AD (1998) A dictionary of English Place Names. Oxford University Press, Oxford. 411pp.

Morris J (1978) Domesday Book, History from the sources, Cheshire (26), Philimore, Chichester.

Morris CH (1975) Report on abandoned mineral workings and possible surface instability problems. County of Cleveland, Department of the County Surveyor and Engineer.63pp.

Notholt AJG and Highley DE (1973) Salt. Mineral Dossier No. 7, Mineral Resources Consultative Committee, H.M.S.O.

London, 36 pp.

Ormerod GW (1848) Outline of he principal Geological features of the Salt-Field of Cheshire and the adjoining districts. Proceedings of the Geological Society. 4: 262-288 and plate 9.

Parkinson C (1884) The Droitwich Brine-springs and Saliferous Marls. Quarterly Journal of the Geological Society. 40: 248256.

Poole EG and Williams BJ (1981) ‘The Keuper Saliferous Beds of the Droitwich area’. Report of the Institute of Geological Sciences, No. 81/2. 19 pp.

Rastell T (1678) An Account of the Salt Waters of Droytwich in Worcestershire, sent by Dr William Cole from Dr Tho. Rastell. Philosophical Transactions. 12: 1059-1064.

Raymond LR (1960) The pre-Permian floor beneath Billingham, County Durham, and structures in the overlying Permian sediments. Quarterly Journal of the Geological Society of London, 116: 297-315.

Room A (1988) Dictionary of place names in the British Isle. Bloomsbury.

Sherlock RL (1921) Rock-salt and brine. Special reports of the mineral resources of Great Britain, Memoir of the Geological Survey. H.M.S.O. London. 122 pp.

Smith DB (1989) The late Permian palaeogeography of north-east England. Proceedings of the Yorkshire Geological Society. 47: 285-312.

Tomlin DM (1982) The salt industry of the River Tees. De Archeologische pers, Nederlands. 109pp.

Walling DE and Webb BW (1981) Water quality. In: Lewin J (ed) British Rivers, Allen and Unwin pp126-169.

Waltham AC (1989) Ground subsidence. Blackie, Glasgow and London. 202p.

Watham AC, Simms MJ, Farrant AR and Goldie HS (1997) Karst and caves of Great Britain. Joint Nature Conservation Committee. Chapman and Hall, London. 358pp.

Whitelock D (1954) The beginnings of English Society. Penguin Books, 256pp.

Wilson AA (1990) The Mercia Mudstone Group (Trias) of the East Irish Sea Basin. Proceedings of the Yorkshire Geological Society. 48: 1-22.

Wilson AA (1993) The Mercia Mudstone Group (Trias) of the Cheshire Basin. Proceedings of the Yorkshire Geological Society. 49: 171-188.

Wilson AA and Evans WB (1990) Geology of the country around Blackpool. Memoir of the British Geological Survey, Sheet 66 (England and Wales), $82 \mathrm{pp}$.

Woodiwiss, S.G. (ed) (1992) Iron Age and Roman salt production and the Medieval town of Droitwich. Excavations at the Old Bowling Green and Friar Street. Council for British Archaeology, Research Report, 81. 223pp and microfiche. Woods, P.J.E. 1973 Potash exploration in Yorkshire: Boulby mine pilot borehole. Transactions of the Institution of Mining and Metallugry. Vol 82, B99-B106. 